\title{
The susceptibility of granulosa cells to apoptosis is influenced by oestradiol and the cell cycle
}

\author{
Susan M Quirk, Robert G Cowan and Rebecca M Harman \\ Department of Animal Science, Cornell University, Ithaca, New York 14850, USA \\ (Requests for offprints should be addressed to S M Quirk, Department of Animal Science, Morrison Hall, Cornell University, Ithaca, NY 14853, USA; Email: \\ smq1@cornell.edu)
}

\begin{abstract}
Experiments were conducted to test whether oestradiol (E2) protects granulosa cells from Fas ligand (FasL)induced apoptosis and whether protection involves modulation of the cell cycle of proliferation. Treatment of cultured bovine granulosa cells with E2 decreased susceptibility to FasL-induced apoptosis. The effects of E2 were mediated through oestrogen receptor and were not mediated by stimulation of IGF production. E2 also increased the percentage of cells progressing from G1 to $\mathrm{S}$ phase of the cell cycle, and increased expression of cyclin D2 protein and the cell proliferation marker Ki67. Progression from G1 to $\mathrm{S}$ phase of the cell cycle was necessary for the protective effect of $\mathrm{E} 2$; blocking progression from $\mathrm{G} 1$ to $\mathrm{S}$ phase with the cdk2 inhibitor roscovitine, or blocking cells in $\mathrm{S}$ phase with hydroxyurea, prevented
\end{abstract}

protection by E2. The stages of the cell cycle during which granulosa cells are susceptible to apoptosis were assessed. First, treatment with the G1 phase blocker, mimosine, protected cells from FasL-induced apoptosis, indicating that cells in G0 or early- to mid-G1 phase are relatively resistant to apoptosis. Secondly, examination of recent DNA synthesis by cells that became apoptotic indicated that apoptosis did not occur in S, G2 or M phases. Taken together, the experiments indicate that cells may be most susceptible to apoptosis at the transition from $\mathrm{G} 1$ to $\mathrm{S}$ phase. E2 stimulates transition from G1 to $\mathrm{S}$ phase and protects against apoptosis only when cell cycle progression is unperturbed.

Journal of Endocrinology (2006) 189, 441-453

\section{Introduction}

Most ovarian follicles fail to develop fully but instead undergo degeneration by apoptosis of follicle cells. Select follicles that evade atresia and reach ovulatory status are thought to be supported by survival pathways stimulated by gonadotrophins and growth factors (Chun \& Hsueh 1998, Johnson 2003). A pathway that mediates apoptosis in numerous cell types including ovarian cells is the Fas pathway. Fas is a cell surface receptor that triggers apoptosis in sensitive cells in response to binding Fas ligand (FasL) (Hengartner 2000). Granulosa and theca cells express both Fas and FasL, and expression is elevated in atretic compared with healthy follicles (Porter et al. 2000, Vickers et al. 2000). Bovine granulosa cells from atretic subordinate follicles are more sensitive to FasL-induced apoptosis than cells from healthy dominant follicles (Porter et al. 2000). Removal of serum from the media of cultured bovine granulosa cells increases expression of Fas and FasL, and induces apoptosis that is at least partially mediated by endogenous Fas/FasL interactions ( $\mathrm{Hu}$ et al. 2001). Induction of apoptosis by addition of exogenous FasL to cultured granulosa cells is inhibited by serum and a number of growth factors (Quirk et al. 2000).
Growth factors that suppressed FasL-induced apoptosis also increased proliferation of granulosa cells (Quirk et al. 2000). This association suggested that the ability of growth factors to inhibit apoptosis might be dependent upon their effects on the cell cycle of proliferation. In rodents and cattle, the highest frequency of atresia occurs in size classes of follicles in which granulosa cells are proliferating rapidly (Pedersen 1970, Hirshfield \& Midgley 1978, Lussier et al. 1987). Follicles are believed to become increasingly dependent upon gonadotrophins and other growth factors for viability during stages of follicle development when rapid granulosa cell proliferation occurs (reviewed in Hirshfield (1991)). The concept that growth factors may promote the survival of granulosa cells by maintaining progression through the cell cycle is supported by increasing evidence that the susceptibility of cells to apoptosis varies with stage of the cell cycle (Meikrantz \& Schlegel 1995, King \& Cidlowski 1998, Guo \& Hay 1999, Schutte \& Ramaekers 2000). We have demonstrated that the ability of insulin-like growth factor-I (IGF-I) to suppress FasL-induced apoptosis of bovine granulosa cells is mediated by the PI3K/Akt pathway and is dependent on unperturbed progression through the cell cycle $(\mathrm{Hu}$ et al. 2004). 
Oestrogen is known to increase proliferation of granulosa cells and to regulate the differentiation of follicle cells (Rao et al. 1978, Rosenfeld et al. 2001, Drummond et al. 2002, Couse et al. 2005). Oestrogen is also thought to be a survival factor in granulosa cells, based primarily on the finding that treatment of immature hypophysectomized rats with implants of diethylstilbesterol (DES) was followed by implant withdrawal-induced apoptosis of granulosa cells in multilayered preantral follicles (Billig et al. 1993). The mechanism for this effect of oestrogen in promoting granulosa cell viability was not determined. In cattle, follicles that are selected for continued growth and development to the ovulatory stage have increased capacity to secrete oestradiol (E2) relative to follicles destined to undergo atresia (Evans \& Fortune 1997, Mihm et al. 2000). Thus, elevated E2 correlates with follicle survival. We hypothesize that the mechanism by which E2 and other growth factors protect against apoptosis is associated with their involvement in promoting progression through the cell cycle. The current study provides evidence in support of this concept. We demonstrate that E2 protects bovine granulosa cells from FasL-induced apoptosis in vitro and that this effect is dependent on progression through the cell cycle. Furthermore, we show that granulosa cells are most susceptible to apoptosis at the $\mathrm{G} 1$ to $\mathrm{S}$ phase transition of the cell cycle.

\section{Materials and Methods}

\section{Materials}

Culture media, fetal bovine serum (FBS), BSA, penicillin, streptomycin and fungizone were obtained from Life Technologies, Inc. Sodium pyruvate, L-glutamine, E2 and bromodeoxyuridine (BrdU) were obtained from Sigma. ICI 182,780 (Fulvestrant) was obtained from AstraZeneca. Tissue culture plates were obtained from Corning-Costar (Cambridge, MA, USA), and slide wells were obtained from Nalge Nunc International (Naperville, IL, USA). Soluble recombinant human FasL was obtained from Upstate Biotechnology (Lake Placid, NY, USA). Cell cycle inhibitors (roscovitine, hydroxyurea and mimosine) were from Calbiochem (San Diego, CA, USA). Rabbit anti-human cyclin D2 (sc-181) was from Santa Cruz Biotechnology (Santa Cruz, CA, USA). Mouse anti-human Ki67 was from Novocastra Laboratories (Newcastle upon Tyne, UK). Mouse anti-human IGF-I receptor (clone 33255.111) was from R\&D Systems (Minneapolis, MN, USA), and mouse anti-BrdU (clone 3D4) was from BD Biosciences (San Diego, CA, USA). Alexa 488-conjugated goat anti-rabbit IgG, Alexa 488-conjugated goat anti-mouse $\operatorname{IgG}$ and propidium iodide (PI) were from Molecular Probes (Eugene, OR, USA).

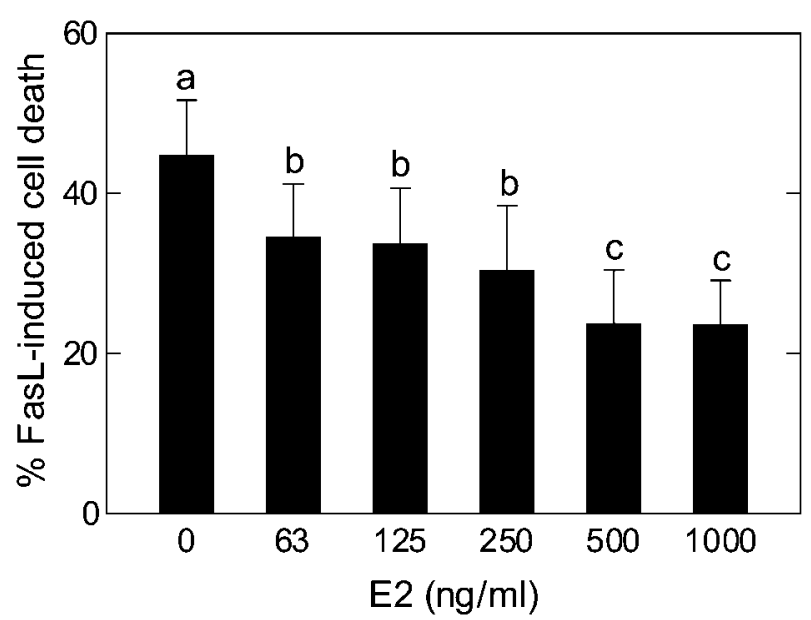

Figure 1 Treatment with E2 protects granulosa cells from FasL-induced cell death. Granulosa cells were cultured for 2 days in media containing FBS and $0-1000 \mathrm{ng} / \mathrm{ml} \mathrm{E2}$. Media were changed to defined media containing the same concentrations of $\mathrm{E} 2(t=0 \mathrm{~h})$, and 0 or $100 \mathrm{ng} / \mathrm{ml} \mathrm{FasL}$ were added to all treatments at $6 \mathrm{~h}$. Numbers of viable cells were determined at $24 \mathrm{~h}$ by cell counts following staining with trypan blue. The percentage of cell death in response to FasL was calculated by comparing the number of viable cells in cultures treated with or without FasL. Bars with different superscripts are significantly different $(P<0 \cdot 05)$.

\section{Cell isolation and culture}

Freshly excised cow ovaries were obtained from an abattoir, transported in saline at $4{ }^{\circ} \mathrm{C}$ (approximately $1.5 \mathrm{~h})$ and processed immediately. Granulosa cells were collected by aspiration of 2-4 $\mathrm{mm}$ follicles and cultured in Dulbecco's modified Eagle's medium (DMEM)-F12 containing $10 \%$ FBS and supplemented with $1 \mathrm{mM}$ pyruvate, $2 \mathrm{mM}$ glutamine, $100 \mathrm{U} / \mathrm{ml}$ penicillin, $100 \mu \mathrm{g} / \mathrm{ml}$ streptomycin and $0.25 \mu \mathrm{g} / \mathrm{ml}$ fungizone. Follicles in this size range contain proliferative granulosa cells. In some experiments, $0-1000 \mathrm{ng} / \mathrm{ml} \mathrm{E} 2$ were added to the media at the time of plating. A dose of $1000 \mathrm{ng} / \mathrm{ml} \mathrm{E} 2$ was used in most experiments because it was determined to be a maximally effective dose in initial dose-response studies (Fig. 1). The concentration of E2 in follicular fluid varies from approximately $0 \cdot 5-20 \mathrm{ng} / \mathrm{ml}$ in bovine follicles of $0 \cdot 5-4 \cdot 5 \mathrm{~mm}$ diameter (Austin et al. 2001) to $1 \mu \mathrm{g} / \mathrm{ml}$ in healthy preovulatory follicles $>15 \mathrm{~mm}$ diameter (Fortune et al. 1988). Cells were plated (day 0) at $5 \times 10^{4}$ cells/well in 96-well plates for cell viability assays, at $1 \times 10^{6}$ cells/well in $35 \mathrm{~mm}$ dishes for flow cytometric analyses or at $2 \times 10^{5}$ cells/well in 8-well slide wells for immunocytochemistry. On day 1 , media were replaced with the same media. On day 2, media were changed to DMEM-F12 supplemented as above but without serum and containing $100 \mathrm{ng} / \mathrm{ml}$ insulin, $5 \mu \mathrm{g} / \mathrm{ml}$ transferrin, $20 \mathrm{nM}$ sodium selenite and $0 \cdot 1 \%$ BSA (ITS). Treatments were applied at this time as described below. The concentration of insulin in ITS is significantly lower than in commercial preparations of ITS 
( $1 \mu \mathrm{g} / \mathrm{ml}$ or greater). In preliminary experiments, a dose of $100 \mathrm{ng} / \mathrm{ml}$ insulin was found to be sufficient to maintain viability of granulosa cells but not to block apoptosis in response to treatment with FasL.

\section{Assay of granulosa cell susceptibility to apoptosis}

On day 2, culture media were changed to ITS, and treatments were applied as described in the Results. Within each replicate of an experiment, each treatment was tested in eight wells. After 6 or $8 \mathrm{~h}$, depending on the experiment, FasL was added at a final concentration of $0 \mathrm{ng} / \mathrm{ml}$ to four wells and $100 \mathrm{ng} / \mathrm{ml}$ to four wells. After $24 \mathrm{~h}$, cells were trypsinized, collected and stained with trypan blue, and live cells were counted in a haemacytometer. The percentage of granulosa cells killed by FasL was calculated for each treatment within an experimental replicate by comparing the mean number of live cells present in the four FasL-treated wells vs the mean number of cells in the four wells receiving no FasL. Each experiment was repeated five times using separate granulosa cell preparations. In some experiments, flow cytometry of cells stained for DNA content with PI was used to determine the percentage of apoptotic cells (described below).

\section{Immunocytochemical assessment of proliferation in cultured granulosa cells}

The effects of the various treatments on the proliferation of granulosa cells was examined by determining the percentage of cells expressing the cell proliferation marker, Ki67, and the cell cycle regulator, cyclin D2. Granulosa cells plated in eight-well slide-well chambers were treated on day 2 with 0 or $1000 \mathrm{ng} / \mathrm{ml} \mathrm{E2}$. Twenty-four hours later, the cells were fixed in cold acetone for $2 \mathrm{~min}$, and stained for Ki67 or cyclin D2 using similar protocols. Fixed cells were incubated with primary antibody $(1 \mu \mathrm{g} / \mathrm{ml}$ mouse anti-human Ki67 or $0.5 \mu \mathrm{g} / \mathrm{ml}$ rabbit anti-human cyclin D2) in PBS-2\% BSA for $1 \mathrm{~h}$ at $37^{\circ} \mathrm{C}$, rinsed, and incubated with secondary antibody $(2 \mu \mathrm{g} / \mathrm{ml}$ goat anti-mouse IgG-Alexa 488 for Ki67 or $1 \mu \mathrm{g} / \mathrm{ml}$ goat anti-rabbit IgG-Alexa 488 for cyclin D2) for $1 \mathrm{~h}$ at $37^{\circ} \mathrm{C}$. After rinsing, cells were counterstained with $1 \mu \mathrm{g} / \mathrm{ml}$ PI. Stained cells were examined under epifluorescent illumination, and coincident images of Alexa 488 and PI fluorescence obtained. The filters used were: for Alexa-488, excitation 460-500 nm and emission 500$540 \mathrm{~nm}$; for PI, excitation 536-556 nm and emission $>590 \mathrm{~nm}$. The number of cells with distinct nuclear Alexa 488 fluorescence and the number of cells with PI fluorescence were used to calculate the percentage of cells expressing Ki67 or cyclin D2. In each experiment, images were obtained from four randomly chosen fields for each treatment, and experiments were repeated 5 times using separate granulosa cell preparations. Cell counts of Alexa 488-positive cells and total cells were determined by two observers without knowledge of treatment.

\section{Cell cycle analysis}

The effects of treatments on the distribution of cells in the cell cycle were determined by flow cytometry of cells stained for DNA content using PI (Hu et al. 2004). Granulosa cells cultured in six-well culture plates were collected by trypsinization, fixed in $80 \%$ ethanol and stored at $4{ }^{\circ} \mathrm{C}$ until staining for flow cytometry. Cells $\left(5 \times 10^{5}\right)$ were stained with $5 \mu \mathrm{g} / \mathrm{ml}$ PI in $0 \cdot 01 \mathrm{M}$ PBS containing $0 \cdot 01 \%$ Triton X-100 and $30 \mu \mathrm{g} / \mathrm{ml}$ DNase-free RNase A. Cells (10000 per sample) were analyzed on a FACScan flow cytometer (Becton, Dickinson and Co, NJ, USA). Data were gated for single cells and DNA content assigned to G0/G1, S or G2/M phases based on the method of Ormerod (1994) using WinMDI software (The Scripps Research Institute, La Jolla, CA, USA).

\section{Flow cytometric detection of BrdU incorporation in apoptotic cells}

Incorporation of BrdU was used in conjunction with PI binding to DNA to examine whether cells residing in $\mathrm{S}$ phase, or which had recently passed through $\mathrm{S}$ phase, were susceptible to apoptosis. On day 2, granulosa cells in six-well plates were treated at $0 \mathrm{~h}$ with 0 or $10 \mu \mathrm{M} \mathrm{BrdU}$ in DMEM-F12-ITS and at $6 \mathrm{~h}$ with 0 or $100 \mathrm{ng} / \mathrm{ml} \mathrm{FasL.}$ At $24 \mathrm{~h}$ cells were trypsinized, resuspended in DMEMF12 and fixed in $80 \%$ ethanol. Detection of BrdU was performed as previously described (Wilson 1994) with minor modifications (Hu et al. 2004). Briefly, cells were pretreated with $100 \mu \mathrm{g} / \mathrm{ml}$ RNase A for 20 min, rinsed in PBS, and treated with $0.1 \mathrm{M} \mathrm{Na}$-citrate in $0.5 \%$ Triton $\mathrm{X}-100$ in PBS for $10 \mathrm{~min}$ on ice. Cells were rinsed in $0 \cdot 01 \mathrm{M}$ Tris buffer containing $10 \mathrm{mM} \mathrm{MgCl}$, DNA was partially digested by addition of $30 \mathrm{U} / \mathrm{ml} \mathrm{BamHI}$ for $30 \mathrm{~min}$, and cells were rinsed in Tris buffer. Cells were incubated with $2 \mu \mathrm{g} / \mathrm{ml}$ mouse anti-BrdU in PBS- $-0.5 \%$ BSA- $0.5 \%$ Tween 20 for $2 \mathrm{~h}$ at room temperature and then with $0.5 \mu \mathrm{g} / \mathrm{ml}$ goat anti-mouse IgG-Alexa 488 in the same buffer for $2 \mathrm{~h}$ at room temperature. The cells were counterstained with PI to measure the DNA content, and 20000 cells were analyzed for both BrdU and PI fluorescence on a FACScan flow cytometer. Events were gated for single cells based on PI fluorescence. Within each experimental replicate, a fluorescent threshold for identification of positive cells was established based on negative control cells that received no BrdU and were processed as described above. The threshold was chosen such that $>95 \%$ of the cells that did not receive BrdU were negative. Cells were assigned to A0 (apoptotic cells that appeared to have sub-diploid content of DNA), G0/G1, S or G2 M phases based on the method of Ormerod (1994) using WinMDI software (The Scripps Research Institute). 
In areas where $\mathrm{A} 0$ or $\mathrm{S}$ phases overlap with cells in G0/G1, and where S phase overlaps with G2/M, cells were assigned to G0/G1 or G2/M respectively, so that cells identified as $\mathrm{A} 0$ or $\mathrm{S}$ phase contained no cells in other phases. Cells within each phase were then separated into those containing $\mathrm{BrdU}$ (i.e. having made new DNA in the last $24 \mathrm{~h}$ of culture) and those not containing $\mathrm{BrdU}$ (i.e. quiescent cells).

\section{Statistical analysis}

Most experiments were analyzed by one-way ANOVA using a randomized complete block design with experimental replicates as blocks. All treatments were applied to each replicate. All data were subjected to, and passed, tests for normality and equality of variance prior to ANOVA. The Student-Newman-Keuls procedure was used for comparison of means when overall significance was observed (Ott \& Longnecker 2001). The percentage of cells staining positively for Ki67 and the percentage of cells staining positively for cyclin D2 were analyzed by paired, two-tailed $t$-tests. Each experimental replicate included both treatments (control and E2) and results from each replicate were paired in the analyses.

\section{Results}

\section{E2 protects cells from FasL-induced cell death by interaction} with oestrogen receptor (ER)

Initial experiments were performed to test whether E2 protects granulosa cells from cell death induced by treatment with FasL. Granulosa cells were plated (day 0) and cultured for 2 days in media containing FBS and doses of E2 from 63 to $1000 \mathrm{ng} / \mathrm{ml}$. On day 2, media were changed to defined media with the same concentrations of E2, and the cells were treated with FasL $6 \mathrm{~h}$ later. Cell viability was determined at $24 \mathrm{~h}$. The percentage of cell death in response to FasL was calculated by comparing the number of cells present in wells treated with FasL to the number of cells in wells treated identically but without FasL (Fig. 1). Treatment with E2 caused a dose-dependent decrease in FasL-induced cell death. At the highest dose of E2, the percentage of cell death was reduced by $47 \%$.

To determine whether the observed effect of E2 is mediated through ER, the ability of the specific ER antagonist, ICI 182,780, to block the effect of E2 was tested. The treatment protocol was designed to allow pretreatment with ICI 182,780 before addition of E2 to cultures. Cells were cultured in media containing FBS in the absence of $\mathrm{E} 2$ for 2 days and were then changed to defined media. After $3.5 \mathrm{~h}$, cells were treated with 0 or $20 \mu \mathrm{M}(12 \cdot 1 \mu \mathrm{g} / \mathrm{ml})$ ICI 182,780 and $0.5 \mathrm{~h}$ later with 0 or $1000 \mathrm{ng} / \mathrm{ml} \mathrm{E} 2(t=0 \mathrm{~h})$. FasL was added to the appropriate cultures $4 \mathrm{~h}$ after E2, and cells were examined at $24 \mathrm{~h}$

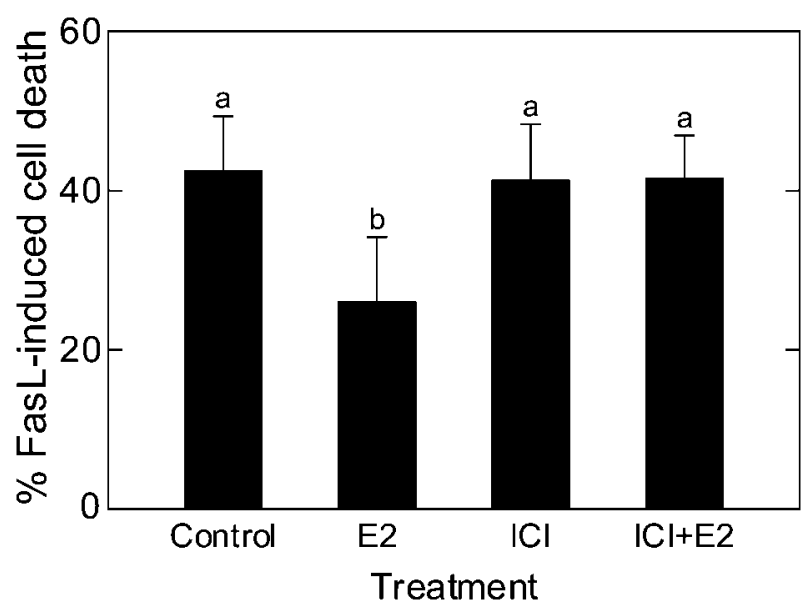

Figure 2 Protection by E2 against FasL-induced cell death is mediated by ER. Granulosa cells in defined media were pretreated with $20 \mu \mathrm{M} \mathrm{ICl} 182,780$, an ER antagonist, and treated $0.5 \mathrm{~h}$ later with 0 or $1000 \mathrm{ng} / \mathrm{ml} \mathrm{E2}(t=0 \mathrm{~h})$. At $4 \mathrm{~h}$ cells were treated with 0 or $100 \mathrm{ng} / \mathrm{ml}$ FasL. Numbers of viable cells were determined at $24 \mathrm{~h}$ by cell counts following staining with trypan blue. The percentage of cell death in response to FasL was calculated by comparing the number of viable cells in cultures treated with or without FasL. Bars represent the means \pm S.E.M. of results obtained in five experiments using separate granulosa cell preparations. Bars with different superscripts are significantly different $(P<0 \cdot 05)$.

for viability. Treatment with E2 protected cells from FasL-induced cell death but pretreatment with ICI 182,780 blocked this effect (Fig. 2).

The number of apoptotic cells in granulosa cell cultures was assessed by analysis of cellular DNA content by flow cytometry of cells stained with PI. The peak of cells with apparent sub-diploid content of DNA (A0 peak) represents apoptotic cells present in the culture $24 \mathrm{~h}$ after treatment with FasL. Treatment with FasL increased the percentage of apoptotic cells from non-detectable to 14\%, and E2 suppressed this effect (Fig. 3). Pretreatment with ICI 182,780 abolished the protective effect of E2. Note that the A0 peak does not represent the cumulative population of cells undergoing apoptosis over $24 \mathrm{~h}$ of culture because many cells in advanced stages of apoptosis are lost by degradation prior to flow cytometry.

\section{Protective effect of E2 is not mediated by IGF}

Experiments were performed to test whether the protective effect of E2 against FasL-induced apoptosis is mediated through induction of IGF secretion by granulosa cells and subsequent effects through IGFR. We have previously shown that treatment of granulosa cells with IGF-I protects cells from FasL-induced apoptosis ( $\mathrm{Hu}$ et al. 2004). Effects mediated through IGFR were assessed using an anti-IGFR antibody that blocks the binding of ligand to the receptor. Cells were cultured in media containing FBS for 2 days. Media were changed to 

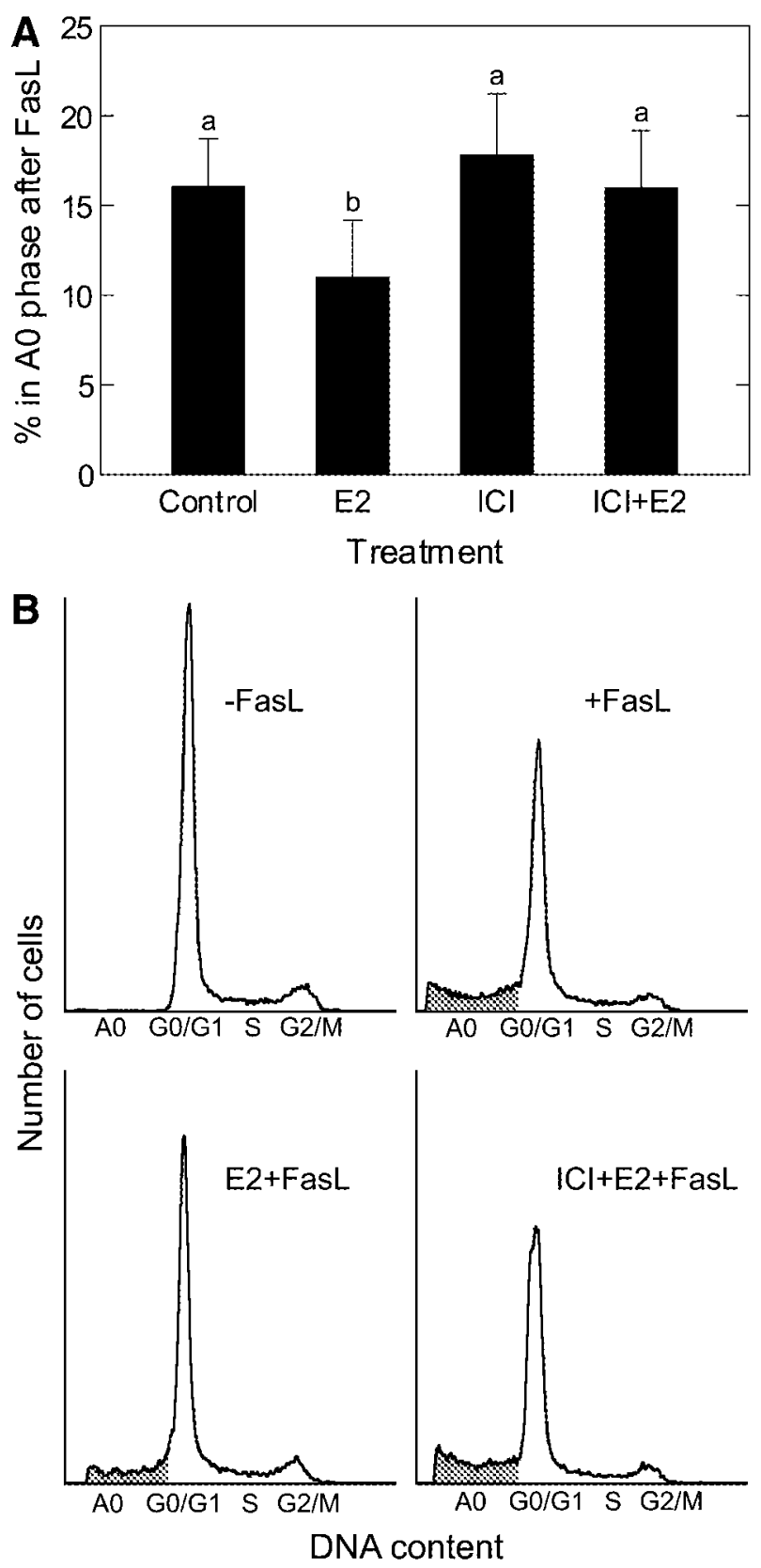

Figure 3 E2 reduces apoptosis in granulosa cells treated with FasL. Granulosa cells in defined media were pretreated with $20 \mu \mathrm{M} \mathrm{ICl}$ 182,780 and treated $0.5 \mathrm{~h}$ later with 0 or $1000 \mathrm{ng} / \mathrm{ml} \mathrm{E2}(t=0 \mathrm{~h})$. At $4 \mathrm{~h}$ cells were treated with 0 or $100 \mathrm{ng} / \mathrm{ml} \mathrm{FasL}$. At $24 \mathrm{~h}$, cells were fixed, stained with $\mathrm{PI}$ and analyzed by flow cytometry to determine the proportion of apoptotic cells. (A) Percentage of cells having apparent sub-diploid content of DNA (A0) characteristic of apoptosis. In cultures not treated with FasL (not shown) the percentage of A0 cells was less than $2 \%$. Bars represent the means \pm S.E.M. of results obtained in five experiments using separate granulosa cell preparations. Bars with different superscripts are significantly different $(P<0 \cdot 05)$. (B) Representative histograms of cell number vs DNA content (PI fluorescence), used to determine the number of cells in different phases of the cell cycle or in the AO region (shaded grey).

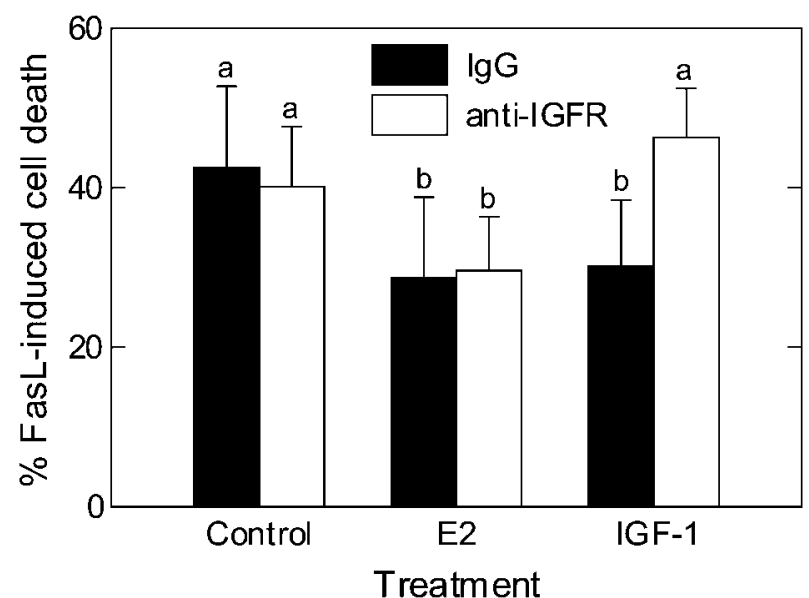

Figure 4 Protection by E2 against FasL-induced cell death does not require IGF signalling. Granulosa cells in defined media were pretreated with $5 \mu \mathrm{g} / \mathrm{ml}$ antibody against IGFR (anti-IGFR) and treated $0.5 \mathrm{~h}$ later with 0 or $1000 \mathrm{ng} / \mathrm{ml} \mathrm{E2}$, or $200 \mathrm{ng} / \mathrm{ml} \mathrm{IGF-I}$ $(t=0 \mathrm{~h})$. At $4 \mathrm{~h}$, cells were treated with 0 or $100 \mathrm{ng} / \mathrm{ml} \mathrm{FasL}$. Numbers of viable cells were determined at $24 \mathrm{~h}$ by cell counts following staining with trypan blue. The percentage of cell death in response to FasL was calculated by comparing the number of viable cells in cultures treated with or without FasL. Bars represent the means \pm S.E.M. of results obtained in five experiments using separate granulosa cell preparations. Bars with different superscripts are significantly different $(P<0 \cdot 05)$.

defined media and $4 \mathrm{~h}$ later cells were treated with $5 \mu \mathrm{g} / \mathrm{ml}$ anti-IGFR antibody or non-specific $\operatorname{IgG}$ as control. Cells were treated $0.5 \mathrm{~h}$ later with 0 or $1000 \mathrm{ng} / \mathrm{ml} \mathrm{E} 2$, or with 0 or $100 \mathrm{ng} / \mathrm{ml} \mathrm{IGF-I}(t=0 \mathrm{~h})$. Cultures were treated $4 \mathrm{~h}$ later with 0 or $100 \mathrm{ng} / \mathrm{ml} \mathrm{FasL}$ and viability was determined at $24 \mathrm{~h}$. Treatment with anti-IGFR antibody had no effect on the ability of E2 to suppress FasL-induced cell death (Fig. 4). In contrast, anti-IGFR antibody blocked interaction of IGF-I with receptor since it prevented the protective effect of IGF-I against FasL-induced cell death (Fig. 4). These results show that the protective effect of E2 is not mediated through IGF.

\section{E2 promotes cell cycle progression}

Several markers of cell cycle progression were examined in granulosa cells cultured in the presence or absence of E2. Ki67, a nuclear protein that is expressed in proliferating cells during S, G2 and M phases and, in some cells, during G1 phase (Endl \& Gerdes 2000, Scholzen \& Gerdes 2000), was expressed in $19 \cdot 4 \pm 2 \cdot 4 \%$ of cells treated with E2 but in only $14 \cdot 0 \pm 1 \cdot 4 \%$ of cells not treated with E2 $(P<0 \cdot 05$; Fig. $5 \mathrm{~A})$. Cyclin D2, a D-type cyclin associated with entry of granulosa cells into the cell cycle (Sicinski et al. 1996), was expressed in $24 \cdot 8 \pm 4 \cdot 4 \%$ of cells treated with E2 but in only $12 \cdot 1 \pm 3 \cdot 0 \%$ of cells not treated with E2 $(P<0 \cdot 05$; Fig. 5B). Granulosa cells 


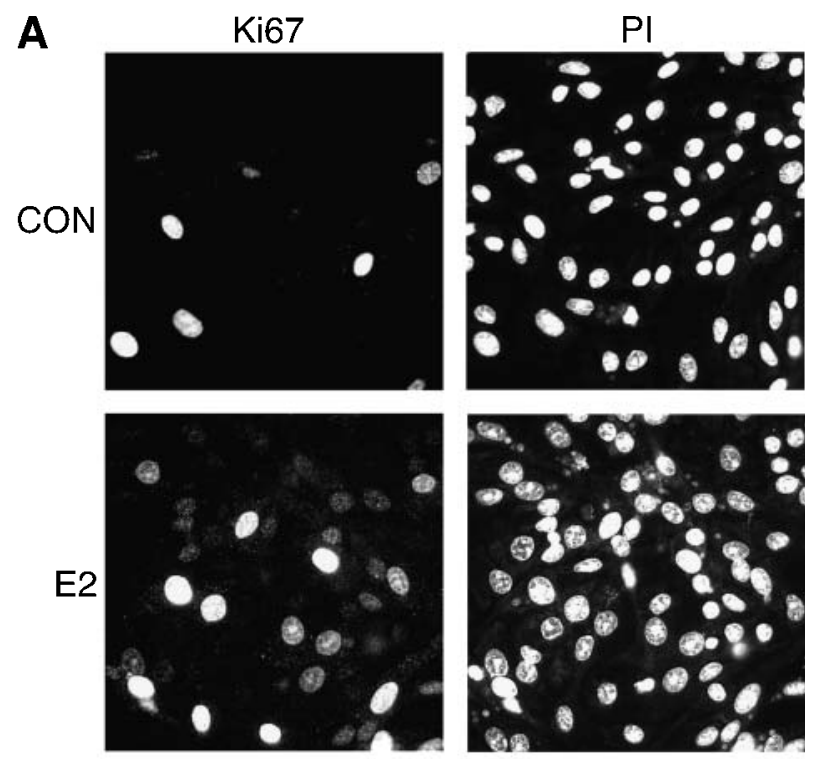

B
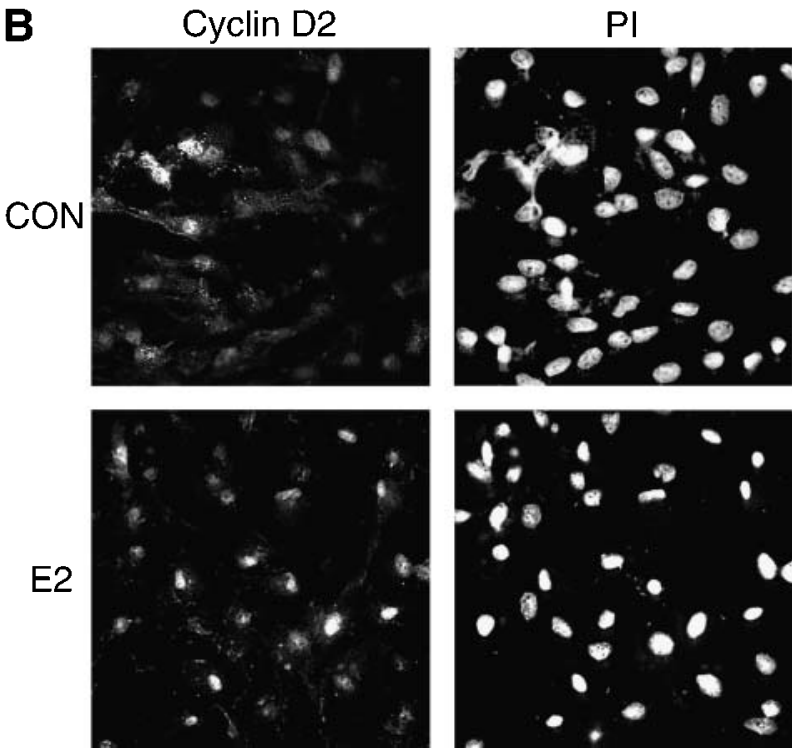

Figure 5 Treatment with E2 increases the percentage of granulosa cells progressing through the cell cycle. Cells were cultured for 2 days in media containing FBS and 0 (CON) or $1000 \mathrm{ng} / \mathrm{ml}$ E2. Media were changed to defined media containing the same concentration of E2 $(t=0 \mathrm{~h})$, and cells were fixed at $24 \mathrm{~h}$. Expression of Ki67 (A) and cyclin D2 (B) were detected by immunocytochemistry and cell nuclei were counterstained with Pl. Images of fluorescence in representative fields are shown. Immunocytochemistry was performed on five separate granulosa cell preparations.

stained for DNA content using PI were analyzed by flow cytometry to determine the percentages of cells in various stages of the cell cycle. Treatment of cells with E2 increased the percentage of cells in $\mathrm{S}$ phase and

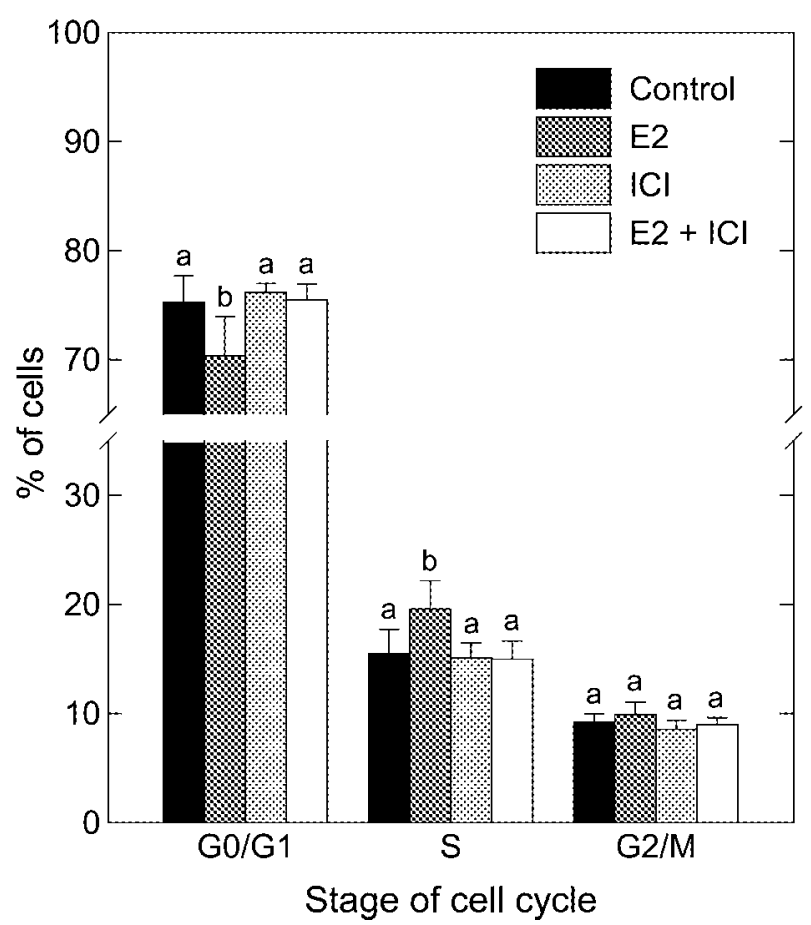

Figure 6 The effect of E2 in increasing progression through the cell cycle is mediated by ER. Granulosa cells in defined media

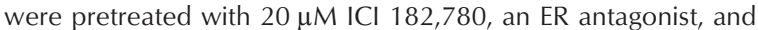
treated $0.5 \mathrm{~h}$ later with 0 or $1000 \mathrm{ng} / \mathrm{ml} \mathrm{E2}(t=0 \mathrm{~h})$. At $4 \mathrm{~h}$, cells were treated with 0 or $100 \mathrm{ng} / \mathrm{ml}$ FasL. The proportion of cells in various stages of the cell cycle (G0/G1, S and G2/M) was determined at $24 \mathrm{~h}$ by flow cytometry of PI-stained cells. Bars represent the means \pm S.E.M. of results obtained in five experiments using separate granulosa cell preparations. Within each stage of the cell cycle, bars with different superscripts are significantly different $(P<0 \cdot 05)$.

decreased the percentage of cells in G0/G1 phases (Fig. 6), indicating that E2 increased progression from G1 to S phase. Pretreatment of cells with ICI 182,780 prevented E2-induced changes in the cell cycle (Fig. 6). Relatively small differences among treatment groups in the percentages of cells positive for markers of proliferation at a single time point represent a larger percentage of cells affected by treatments over a $24 \mathrm{~h}$ period of culture.

Protection from apoptosis by E2 requires cell cycle progression

The results presented above demonstrate two effects of E2 on granulosa cells: protection against FasL-induced apoptosis and promotion of cell cycle progression. Experiments were performed to test whether cell cycle progression was necessary for the protective effect of E2 against apoptosis. The effects of the drugs roscovitine (which inhibits cyclin-dependent kinase 2 and blocks cells at the G1/S interface) and hydroxyurea (HU; which blocks cells in $\mathrm{S}$ phase) were determined. Granulosa cells were cultured for 2 days in media containing FBS and 0 or $1000 \mathrm{ng} / \mathrm{ml} \mathrm{E} 2$. 


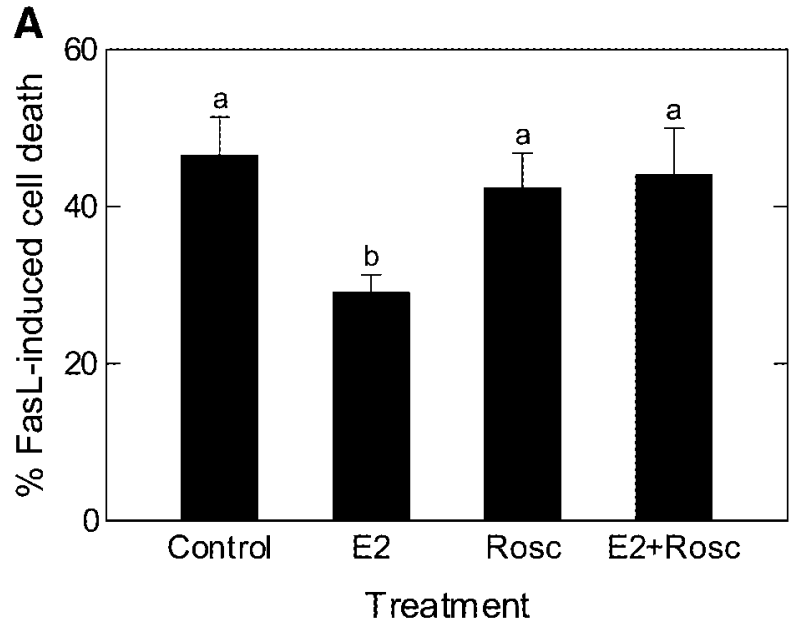

B

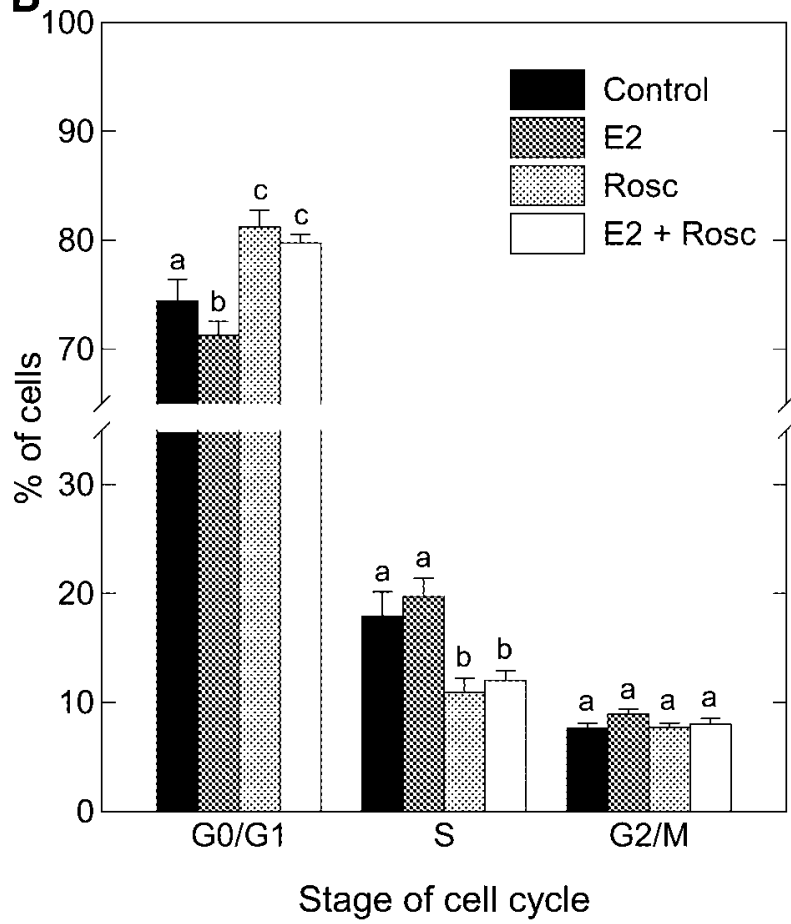

Figure 7 Protection by E2 against FasL-induced cell death is prevented by blocking at the $\mathrm{G} 1 / \mathrm{S}$ interface. Granulosa cells were cultured for 2 days in media containing FBS and 0 or $1000 \mathrm{ng} / \mathrm{ml} \mathrm{E2}$. Media were changed to defined media containing the same concentration of $\mathrm{E} 2$ and 0 or $20 \mu \mathrm{M}$ roscovitine, which blocks cells at the G1/S interface $(t=0 \mathrm{~h}$ ). (A) Percentage of cell death in response to FasL. At $6 \mathrm{~h}, 0$ or $100 \mathrm{ng} / \mathrm{ml}$ FasL were added to all treatments. Numbers of viable cells were determined at $24 \mathrm{~h}$ by cell counts following staining with trypan blue. The percentage of cell death in response to Fas $L$ was calculated by comparing the number of viable cells in cultures treated with or without FasL. (B) Cell cycle stages in cells treated with or without E2 or roscovitine. Cells were collected at $24 \mathrm{~h}$, stained with $\mathrm{Pl}$, and DNA content determined by flow cytometry. Bars represent the means \pm S.E.M. of results obtained in five experiments using separate granulosa cell preparations. Within each panel, and for a given stage of the cell cycle, bars with different superscripts are significantly different $(P<0 \cdot 05)$.
Media were then changed to the defined media with or without E2, and with 0 or $20 \mu \mathrm{M}$ roscovitine or with 0 or $25 \mu \mathrm{g} / \mathrm{ml} \mathrm{HU}(t=0 \mathrm{~h})$. Cultures were treated $6 \mathrm{~h}$ later with 0 or $100 \mathrm{ng} / \mathrm{ml} \mathrm{FasL}$, and cell viability assays and cell cycle analysis were done at $24 \mathrm{~h}$. As expected, treatment with E2 decreased the percentage of cell death in response to FasL (Fig. 7A). Treatment with roscovitine alone had no effect on FasL-induced cell death but treatment with both roscovitine and $\mathrm{E} 2$ prevented the protective effect of E2 (Fig. 7A). Cell cycle analysis confirmed that treatment with roscovitine inhibited cell cycle progression, as evidenced by an increase in the percentage of cells in G0/G1 phases and a decrease in the percentage of cells in $\mathrm{S}$ phase (Fig. 7B). Thus, the protective effect of E2 was abolished when progression from $\mathrm{G} 1$ to $\mathrm{S}$ phase was suppressed. HU had no effect alone but prevented the protective effect of E2 against FasL-induced cell death (Fig. 8A). Analysis of the cell cycle showed that $\mathrm{HU}$ treatment alone and in the presence of E2 blocked cells in S phase (Fig. 8B). Examination of cell cycle histograms indicates that most of these cells were in early-S phase, suggesting that synthesis of DNA was reduced relative to that normally observed in $S$ phase (data not shown).

Granulosa cells in G0 and early- to mid-G1 phases are relatively resistant to FasL-induced apoptosis

Studies in a variety of cell types, including studies in our laboratory with bovine granulosa cells, have suggested that quiescent cells are relatively resistant to apoptosis (Quirk et al. 2004). In contrast, proliferative granulosa cells may be susceptible to apoptosis unless protected by growth factors such as IGF-I (Hu et al. 2004). We therefore compared the effects of E2 (which promotes G1 to $\mathrm{S}$ phase progression) and mimosine (which blocks cells in early- to mid-G1 phase) on FasL-induced cell death. Granulosa cells were cultured for 2 days in media containing FBS and 0 or $1000 \mathrm{ng} / \mathrm{ml} \mathrm{E2}$. Media were then changed to defined media with or without E2, and containing 0 or $1000 \mu \mathrm{M}$ mimosine $(t=0 \mathrm{~h}$ ). Cultures were treated $6 \mathrm{~h}$ later with 0 or $100 \mathrm{ng} / \mathrm{ml} \mathrm{FasL}$, and cell viability and distribution in the cell cycle were determined at $24 \mathrm{~h}$. Treatment with either mimosine or E2 was equally protective against FasL-induced cell death (Fig. 9A). Co-treatment with mimosine and E2 did not further reduce cell death in response to FasL (Fig. 9A). Analysis of the cell cycle by flow cytometry confirmed that mimosine had the expected effect of blocking cells in G1 phase; mimosine increased the percentage of cells in G0/G1 and decreased the percentage of cells in $\mathrm{S}$ and G2/M phases. E2 increased progression from G0/G1 to $\mathrm{S}$ phase and this effect was blocked by co-treatment with mimosine (Fig. 9B). These results show that treatment with mimosine or E2 protects cells against apoptosis. The protective effect of mimosine is associated with blockage 


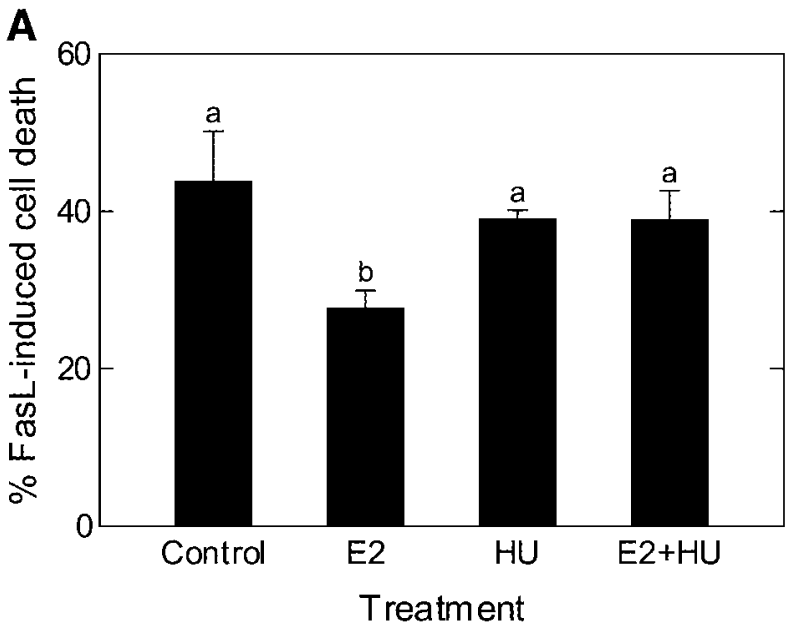

B

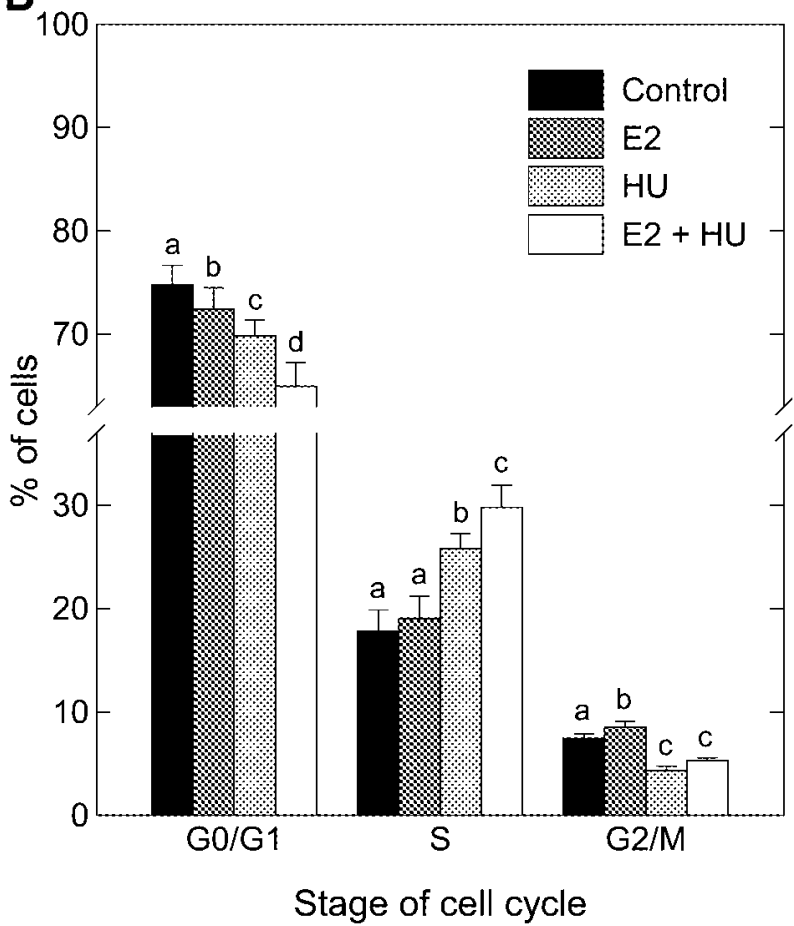

Figure 8 Protection by E2 against FasL-induced cell death is prevented by blocking in S phase. Granulosa cells were cultured for 2 days in media containing FBS and 0 or $1000 \mathrm{ng} / \mathrm{ml} \mathrm{E2}$. Media were changed to defined media containing the same concentration of E2 and 0 or $25 \mu \mathrm{g} / \mathrm{ml} \mathrm{HU}$, which blocks cells in $\mathrm{S}$ phase $(t=0 \mathrm{~h})$. (A) Percentage of cell death in response to FasL. At $6 \mathrm{~h}, 0$ or $100 \mathrm{ng} / \mathrm{ml} \mathrm{FasL}$ were added to all treatments. Numbers of viable cells were determined at $24 \mathrm{~h}$ by cell counts following staining with trypan blue. The percentage of cell death in response to FasL was calculated by comparing the number of viable cells in cultures treated with or without FasL. (B) Cell cycle stages in cells treated with or without E2 or HU. Cells were collected at $24 \mathrm{~h}$, stained with $\mathrm{PI}$, and DNA content determined by flow cytometry. Bars represent the means \pm S.E.M. of results obtained in five experiments using separate granulosa cell preparations. Within each panel, and for a given stage of the cell cycle, bars with different superscripts are significantly different $(P<0 \cdot 05)$.
A

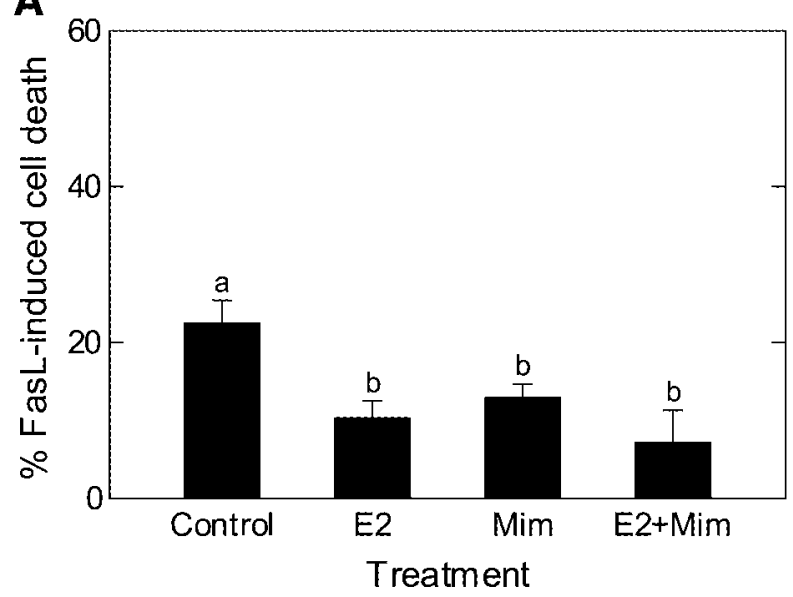

B

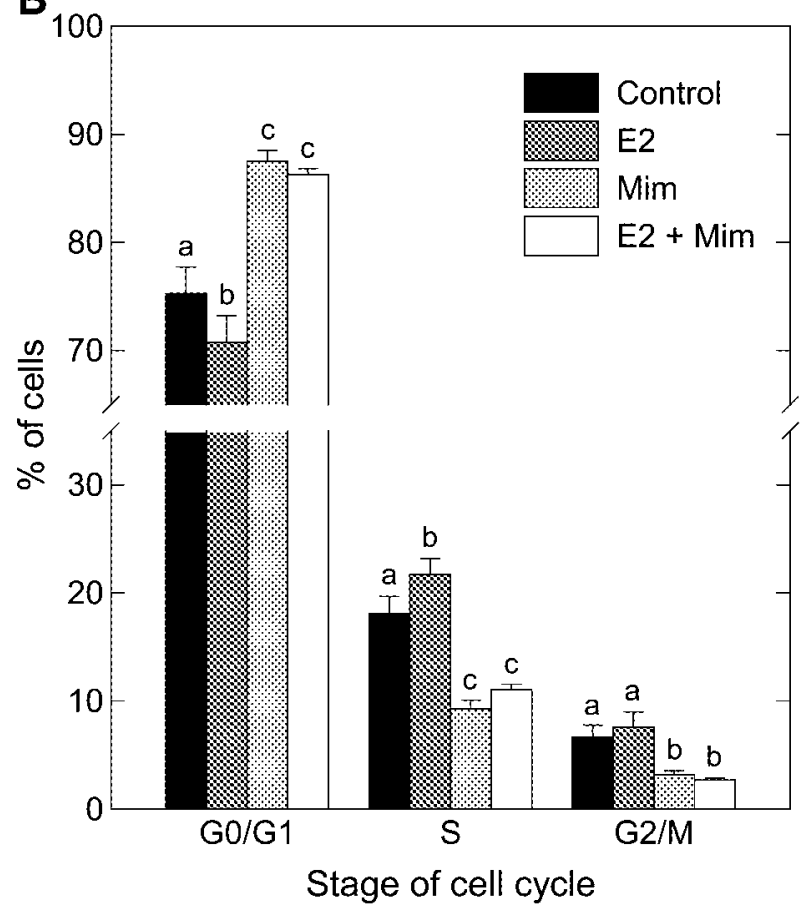

Figure 9 Granulosa cells are relatively resistant to FasL-induced cell death in G0 and early-G1 phases. Granulosa cells were cultured for 2 days in media containing FBS and 0 or $1000 \mathrm{ng} / \mathrm{ml}$ E2. Media were changed to defined media containing the same concentration of E2 and 0 or $1000 \mu \mathrm{M}$ mimosine (Mim), which blocks cells in G1 $(t=0 \mathrm{~h})$. (A) Percentage of cell death in response to FasL. At $6 \mathrm{~h}, 0$ or $100 \mathrm{ng} / \mathrm{ml}$ FasL were added to all treatments. Numbers of viable cells were determined at $24 \mathrm{~h}$ by cell counts following staining with trypan blue. The percentage of cell death in response to FasL was calculated by comparing the number of viable cells in cultures treated with or without FasL. (B) Cell cycle stages in cells treated with or without mimosine. Cells were collected at $24 \mathrm{~h}$, stained with PI, and DNA content determined by flow cytometry. Bars represent the means \pm S.E.M. of results obtained in five experiments using separate granulosa cell preparations. Within each panel, and for a given stage of the cell cycle, bars with different superscripts are significantly different $(P<0 \cdot 05)$. 
of cells in early- to mid-G1 phase. The protective effect of E2 is associated with increased progression from G1 to $\mathrm{S}$ phase.

Granulosa cells are susceptible to FasL during progression from G1 to $S$ phase

The data presented above indicate that cells are relatively resistant to apoptosis in G0 and early-G1 phases of the cell cycle. Experiments using roscovitine suggest that cells progressing through the G1 to S phase transition may be more susceptible to apoptosis than quiescent cells. The final experiment used a combination of cell labelling for DNA synthesis and flow cytometry to determine whether cells undergo apoptosis during the $\mathrm{G} 1$ to $\mathrm{S}$ transition or in later stages (S, G2 or M). Granulosa cells that had entered or passed through $\mathrm{S}$ phase were labelled by culturing in the presence of the thymidine analogue BrdU, and FasL was added to cultures $6 \mathrm{~h}$ later. At $24 \mathrm{~h}$ cells were stained with both an anti-BrdU antibody and PI, and flow cytometry was performed to determine the percentages of BrdU-labelled cells in various stages of the cell cycle and in the A0 region of apoptotic cells. The rationale was that if FasL-induced apoptosis occurs during the $\mathrm{G} 1$ to $\mathrm{S}$ phase transition, apoptotic cells would not have synthesized DNA during the culture period and would not be labelled with BrdU. If FasL-induced apoptosis occurs during S, G2 or $\mathrm{M}$ phase, a relatively high percentage of apoptotic cells would be labelled with BrdU. Overall, $32 \pm 5 \%$ of cells had incorporated BrdU during the treatment period. As shown in Fig. 10A, most of the cells in $\mathrm{S}$ and G2/M phases had incorporated BrdU, although about $40 \%$ of the cells in $\mathrm{S}$ and G2/M phases were unlabelled. The majority of cells in $\mathrm{S}$ phase that did not incorporate BrdU were in early-S phase and had levels of BrdU-associated fluorescence just below the threshold for positive cells (marked with a dashed line in panels in Fig. 10B). Among G2/M phase cells that did not incorporate BrdU, approximately half were just below the threshold. The remainder, which had low fluorescence, probably include the small number of cell doublets which escape gating for single cells and are thus negative for BrdU. Cells in G0/G1 that were positively stained for BrdU (25\%) probably represent cells that had incorporated BrdU during $S$ phase and re-entered G0/G1 during the $24 \mathrm{~h}$ of culture. The percentage of cells in the A0 peak positively staining for BrdU was $17 \%$, significantly lower than the percentage of BrdU-labelled cells in each phase of the cell cycle $(P<0 \cdot 05$; Fig 10A). The data indicate that cells that became apoptotic had not entered into or passed through $\mathrm{S}$ phase, as evidenced by their predominant lack of BrdU labelling. Since cells in G0 and early G1 were shown above to be resistant to apoptosis (Fig. 9), and cells marked for passage through S, G2 or M phases are not among the apoptotic cells, it can be concluded that apoptosis occurs predominantly during the $\mathrm{G} 1$ to $\mathrm{S}$ transition.
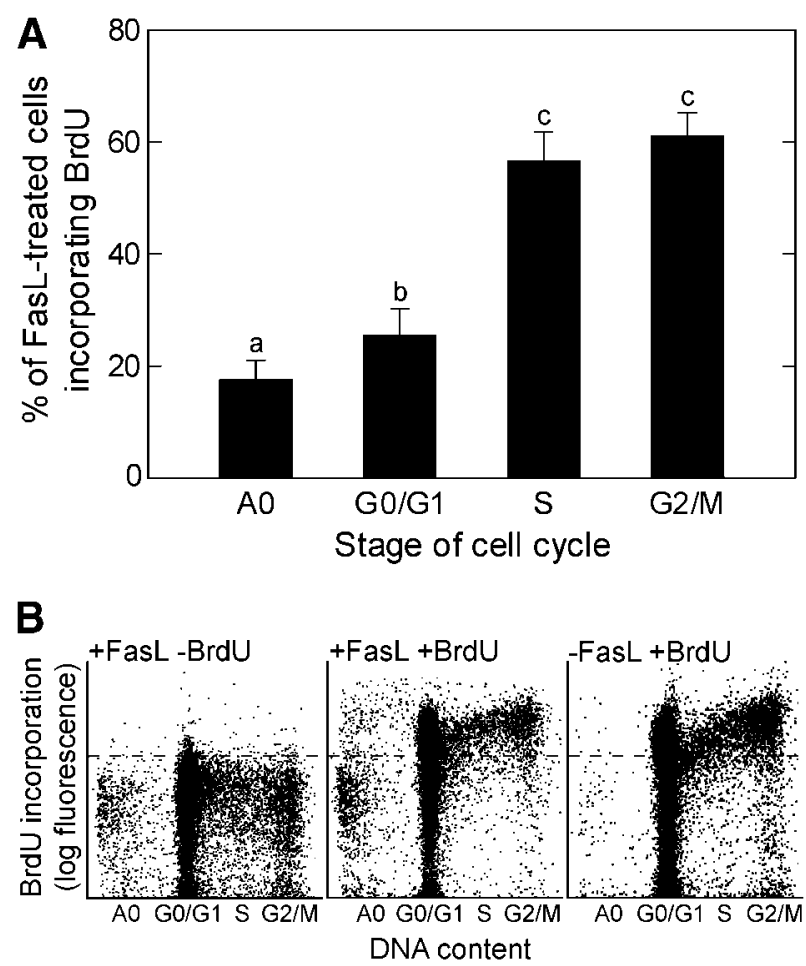

Figure 10 FasL-induced apoptosis of granulosa cells occurs predominantly at the G1 to S phase transition. Granulosa cells in defined media were treated with 0 or $10 \mu \mathrm{M} \mathrm{BrdU}(t=0 \mathrm{~h})$, and with 0 or $100 \mathrm{ng} / \mathrm{ml}$ FasL at $6 \mathrm{~h}$. BrdU is incorporated into cellular DNA during $\mathrm{S}$ phase. At $24 \mathrm{~h}$, cells that had passed through $S$ phase in the presence of BrdU were detected by immunofluorescence using an anti-BrdU antibody. Cells were co-stained with PI and analyzed by flow cytometry. Cells were categorized as apoptotic (A0) or in $\mathrm{G} 0 / \mathrm{G} 1, \mathrm{~S}$ or G2/M phases based on Pl fluorescence. In cultures receiving BrdU, the percentage of cells positively labelled with BrdU in each stage was determined. (A) Percentage of cells in $\mathrm{AO}$ or in each stage of the cell cycle that incorporated BrdU in cultures of granulosa cells treated with FasL. Bars represent the means \pm S.E.M. of results obtained in five experiments using separate granulosa cell preparations. Bars with different superscripts are significantly different $(P<0 \cdot 05)$. (B) Representative dot plots of BrdU incorporation vs DNA content (PI fluorescence). Each dot represents a single cell. The left panel shows the pattern of fluorescence in cells not treated with BrdU. The fluorescent threshold, above which cells are considered positively stained for $\mathrm{BrdU}$, is indicated by the dashed line. The center panel shows one of the samples used to generate the data presented in panel A. Note that cells in the A0 region are predominantly below the threshold for BrdU fluorescence. The right panel shows a control sample not treated with FasL, with few cells in the $\mathrm{A} 0$ region.

\section{Discussion}

The major findings of this study are that the mechanism whereby E2 protects granulosa cells from apoptosis is dependent on progression through the cell cycle and that granulosa cells are most susceptible to apoptosis at the G1 
to $S$ transition of the cell cycle. The data show for the first time that E2 protects granulosa cells against apoptosis induced by treatment with FasL. Furthermore, this effect is mediated through ER and is dependent upon progression through the cell cycle. Fas and FasL are expressed in granulosa and theca cells at higher levels in atretic vs healthy follicles in a number of species (Hakuno et al. 1996, Kondo et al. 1996, Kim et al. 1998, Porter et al. 2000, Bridgham \& Johnson 2001) and cells from healthy bovine follicles are more resistant to FasL-induced apoptosis than cells from atretic follicles (Porter et al. 2000). A number of growth factors - including IGF-I, fibroblast growth factor (FGF) and epidermal growth factor (EGF) - as well as serum, suppress FasL-induced apoptosis of granulosa cells in vitro (Quirk et al. 2000, Hu et al. 2001). Interestingly, growth factors that protected against FasL-induced apoptosis also increased cell proliferation (Quirk et al. 2000, Hu et al. 2004). This suggested the possibility that the protective effect of mitogens against apoptosis may be dependent upon their effects on the cell cycle. The current study focused on E2 because of its importance in follicular development and granulosa cell proliferation.

Treatment of granulosa cells with E2 increased progression from G1 to $S$ phase of the cell cycle and this effect was mediated through ER. This was demonstrated by a decrease in the percentage of cells in G0/G1 and an increase in the percentage of cells in $\mathrm{S}$ phase in response to treatment with E2; however, this response was not observed with E2 in the presence of the ER antagonist ICI 182,780. E2 also increased the percentage of cells staining positively for the cell proliferation marker Ki67, and for cyclin D2, a cyclin critical for entry of cells into the cell cycle and progression through G1 phase (Sherr \& Roberts 1999). Cyclin D2 is the critical D-type cyclin required for proliferation of granulosa cells (Sicinski et al. 1996). Our findings with bovine granulosa cells are consistent with the previous observations that treatment of immature, hypophysectomized rats with E2 promoted the proliferation of granulosa cells (Rao et al. 1978) and increased levels of cyclin E protein (Robker \& Richards 1998a) and that E2 increased cyclin D2 mRNA levels in cultured granulosa cells from immature rats by an ER-mediated mechanism (Robker \& Richards 1998b). The ER antagonist used in our study inhibits actions of E2 through both ER $\alpha$ and ER $\beta$. The data presented, therefore, do not distinguish between an effect of E2 through $\mathrm{ER} \alpha$ or ER $\beta$. It is possible, however, that effects may be mediated through ER $\beta$ since it is the predominant form of ER in granulosa cells of the cow and rodents (Rosenfeld et al. 1999; reviewed in Couse et al. (2005)). Furthermore, the phenotypes of mice null for ER $\beta$ or $\mathrm{ER} \alpha$ indicate that $\mathrm{ER} \beta$ is more critical for intraovarian effects than ER $\alpha$ (Couse et al. 2005).

The importance of cell cycle progression for the protective effect of E2 against FasL-induced apoptosis was tested using drugs that prevent cell cycle progression. Treatment of granulosa cells with roscovitine blocked progression from G0/G1 to $S$ phase and prevented the protective effect of E2 against FasL-induced apoptosis. Treatment with HU blocked cells in $\mathrm{S}$ phase and this also prevented protection by E2. These results indicate that protection by E2 is dependent upon uninterrupted progression through G1 and S phases of the cell cycle. We previously reported that treatment with IGF-I protects bovine granulosa cells from FasL-induced apoptosis (Quirk et al. 2000, Hu et al. 2004). The mechanism of action of IGF-I has similarities to what we have observed for E2. Protection by IGF-I is associated with increased progression from G1 to $\mathrm{S}$ phase and is dependent upon uninterrupted progression through the cell cycle ( $\mathrm{Hu}$ et al. 2004). Thus, two different agonists, E2 and IGF-I, which are known to play critical roles in folliculogenesis, protect against apoptosis by mechanisms that involve modulation of the cell cycle. These observations may be relevant to mechanisms that promote follicle development in vivo since selection of the healthy dominant follicle in cattle is associated with increased intrafollicular E2 and increased bioavailability of IGF (Mihm et al. 2000, Austin et al. 2001, Rivera et al. 2001). Although the effect of E2 to protect against FasL-induced apoptosis has similarities to what was observed for IGF-I, the effect of E2 is not mediated by stimulation of IGF production by granulosa cells (Hsu \& Hammond 1987). This was demonstrated by failure of an anti-IGFR antibody, which effectively blocked protection by IGF-I, to block protection by E2.

Granulosa cells appear to be relatively resistant to apoptosis in G0/early-G1 phases of the cell cycle. Treatment with the drug mimosine blocked cells in G1 phase of the cell cycle and this was associated with increased resistance to FasL-induced apoptosis. Treatment with both mimosine and E2 did not further suppress FasL-induced apoptosis. This suggests that protection by E2 and mimosine are mediated differently. While mimosine blocked cells in G1 phase of the cell cycle, E2 promoted progression from G1 to $\mathrm{S}$ phase. Thus, the protective effect of mimosine is associated with blocking cells in G0 or earlyto mid-G1 phase while the protective effect of E2 is associated with increased progression from $\mathrm{G} 1$ to $\mathrm{S}$ phase. The finding that granulosa cells in G0/G1 are resistant to apoptosis is consistent with our previous study which demonstrated that granulosa cells from bovine preovulatory follicles that have been exposed to a luteinizing hormone (LH) surge in vivo are resistant to apoptosis and that this effect is dependent upon their withdrawal from the cell cycle (Porter et al. 2001, Quirk et al. 2004). Interestingly, in GDF-9 null mice, the defect in proliferation of granulosa cells and subsequent formation of luteinized nests of cells is associated with lack of granulosa cell apoptosis (Elvin et al. 1999). Studies on neuroblastoma cells (Poluha et al. 1996) and myoblasts (Wang \& Walsh 1996) have also shown that terminal differentiation and 
associated withdrawal from the cell cycle promote resistance to apoptosis. In addition, members of the bcl-2 family of proteins, which are involved in supporting cell survival, are reported to prevent quiescent cells from entering the cell cycle (Schutte \& Ramaekers 2000).

The protective effect of E2 is associated with increased progression from $\mathrm{G} 1$ to $\mathrm{S}$ phase and can be prevented by drugs that interfere with $\mathrm{G} 1$ to $\mathrm{S}$ phase progression. These findings suggest that granulosa cells may be most susceptible to apoptosis, and dependent upon growth factors for survival, at the transition from G1 to $S$ phase of the cell cycle. We tested this hypothesis by labelling granulosa cells synthesizing DNA in S phase, by incorporation of the thymidine analogue BrdU, and determining the fate of cells after treatment with FasL. Analysis of the DNA content of cells by flow cytometry showed that most apoptotic cells, identified by sub-diploid content of DNA, had not incorporated BrdU. The percentage of apoptotic cells that had incorporated BrdU was lower than the percentage of cells incorporating BrdU in any of the cell cycle stages, including G0/G1. This indicates that most of the cells that were susceptible to FasL-induced apoptosis during the $24 \mathrm{~h}$ culture period had not synthesized DNA during $\mathrm{S}$ phase of the cell cycle or reached G2/M phase. Taken together with our finding that blockage of granulosa cells in early- to mid-G1 phase of the cell cycle using mimosine protected against FasL-induced cell death, the results suggest that cells may undergo apoptosis predominantly at the G1 to $\mathrm{S}$ phase transition. Our data show that cells are most sensitive to apoptosis at the G1/S interface, E2 increases the passage of cells from G1 through the G1/S interface to $\mathrm{S}$ phase, and yet E2 protects cells from apoptosis. Two different mechanisms can be proposed to account for this. One is that E2 specifically protects cells as they move from G1 to $S$ phase. The second possibility is that cells that enter the cell cycle but do not have critical support, whether from E2 or from growth factors, will remain at the G1/S interface and succumb to apoptosis. Cells that do have support will proceed rapidly into $S$ phase, thus limiting their susceptibility to apoptosis. The relationship between the cell cycle and susceptibility to apoptosis in granulosa cells is similar to what has been reported for T cells: agents that block the cell cycle in early G1 induce resistance of T cells to apoptosis while agents that block at the $\mathrm{G} 1$ to $\mathrm{S}$ phase transition increase apoptosis (Meikrantz \& Schlegel 1995, Lissy et al. 1998).

In the current study, serum-containing media were used for the first 2 days of culture to promote cell attachment and viability. Media were then changed to serum-free media supplemented with ITS to study susceptibility to FasL-induced apoptosis. While bovine granulosa cells are resistant to FasL-induced apoptosis in the presence of serum, shifting cells to a more defined media containing $100 \mathrm{ng} / \mathrm{ml}$ insulin generates cultures in which at least a portion of the cells undergo apoptosis in response to treatment with FasL (Quirk et al. 2000). These con- ditions were used in our previous studies to examine the effect of various growth factors on susceptibility to FasLinduced apoptosis (Quirk et al. 2000, Hu et al. 2004). A concern is the tendency of granulosa cells to differentiate toward a luteal phenotype when cultured in the presence of serum. When granulosa cells luteinize after exposure to the LH surge in vivo, they exit the cell cycle (demonstrated in cows (Quirk et al. 2004), primates (Chaffin et al. 2001) and rodents (Robker \& Richards 1998a, 1998b)). In cattle, granulosa cells of preovulatory follicles exit the cell cycle within $12 \mathrm{~h}$ after the LH surge, as demonstrated by examination of cell proliferation markers, cell cycle profiles and expression of cell cycle regulatory proteins (Quirk et al. 2004). In the current experiments, granulosa cells isolated from $2-4 \mathrm{~mm}$ follicles and initially cultured in serum-containing media continued to proliferate; the cells expressed Ki67 and cyclin D2, incorporated BrdU into DNA and were observed in S and G2/M phases of the cell cycle. Therefore, under the culture conditions used, granulosa cells continue to proliferate, a characteristic of non-luteinized granulosa cells. This facilitated the study of interactions between the cell cycle in proliferating cells and their susceptibility to apoptosis.

A previous study showed that treatment of immature hypophysectomized rats with implants of DES followed by implant withdrawal induced a wave of apoptosis in the granulosa cells of multilayered preantral follicles (Billig et al. 1993). The mechanism for the protective effect of DES was not determined. In this animal model, DES is known to promote proliferation of granulosa cells leading to development of follicles with multiple layers of granulosa cells and the absence of an antral cavity. Withdrawal of DES support, therefore, probably removes oestrogenic effects on cell proliferation as well as other possible effects on cell survival pathways. A possible role of the transcription factor, nuclear factor $(\mathrm{NF}) \kappa \beta$, in mediating the anti-apoptotic effect of E2 in bovine granulosa cells has been suggested (Valdez \& Turzillo 2005). Elevated production of $\mathrm{E} 2$ by bovine granulosa cells in vitro was associated with higher levels of NFK $\beta$ activity and fewer cells in early apoptosis. In addition, levels of active NFK $\beta$ in the nucleus of granulosa cells of dominant follicles were highest in follicles with elevated concentrations of E2 in follicular fluid (Valdez \& Turzillo 2005). The association between NFK $\beta$ and cell survival in bovine granulosa cells is consistent with studies on rodent granulosa cells that suggested a pro-survival role of NFK $\beta$ (Xiao et al. 2001, Wang et al. 2002, Xiao et al. 2002). In addition to promoting cell survival, NFK $\beta$ stimulates cell proliferation in a manner similar to E2 by increasing expression of cyclin D (Guttridge et al. 1999, Joyce et al. 2001). It is therefore possible that like E2, NFK $\beta$ may promote resistance to apoptosis by effects on the cell cycle.

In summary, protection by $\mathrm{E} 2$ against apoptosis requires progression through the cell cycle. Granulosa cells may be most susceptible to apoptosis at the transition from G1 to 
$S$ phase of the cell cycle and relatively resistant in the quiescent state. Our findings with cells in vitro are consistent with events in vivo. In cattle and rodents, the frequency of atresia is highest in follicle classes in which cell proliferation is greatest (Pedersen 1970, Hirshfield \& Midgley 1978, Lussier et al. 1987). Follicles within these classes are dependent upon gonadotrophins and growth factors for continued growth and survival. It is noteworthy that during the normal process of follicular atresia, granulosa cells do not undergo apoptosis synchronously (Hirshfield \& Midgley 1978), suggesting differences in the susceptibility of cells within a follicle to apoptosis. Initiation of apoptosis may be dependent upon stage of the cell cycle and may reflect the asynchronous proliferation of cells in the follicle. Failure of granulosa cells to receive signals for continued proliferation and the absence of signals to induce terminal differentiation and associated withdrawal from the cell cycle probably trigger apoptosis. The effects of E2 and growth factors such as IGF-I (Hu et al. 2004) in protecting against apoptosis are linked to their effects in promoting granulosa cell proliferation. Fas and other pathways for apoptosis are functional in numerous cell types and are triggered by adverse conditions that are cell-type specific. It seems likely that sensitivity to Fas-mediated apoptosis in additional cell types may be dependent upon stage of the cell cycle.

\section{Funding}

This work was supported by National Institutes of Health grant HD 32535. The authors declare that there is no conflict of interest that would prejudice the impartiality of this scientific work.

\section{References}

Austin EJ, Mihm M, Evans ACO, Knight PG, Ireland JLH, Ireland JJ \& Roche JF 2001 Alterations in intrafollicular regulatory factors and apoptosis during selection of follicles in the first follicular wave of the bovine estrous cycle. Biology of Reproduction 64 839-848.

Billig H, Furuta I \& Hsueh AJW 1993 Estrogens inhibit and androgens enhance ovarian granulosa cell apoptosis. Endocrinology 133 2204-2212.

Bridgham JT \& Johnson AL 2001 Expression and regulation of Fas antigen and tumor necrosis factor receptor type I in hen granulosa cells. Biology of Reproduction 65 733-739.

Chaffin CL, Schwinof KM \& Stouffer RL 2001 Gonadotropin and steroid control of granulosa cell proliferation during the periovulatory interval in Rhesus monkeys. Biology of Reproduction $65755-762$.

Chun S-Y \& Hsueh AJW 1998 Paracrine mechanisms of ovarian follicle apoptosis. Journal of Reproductive Immunology 39 63-75.

Couse JF, Yates MM, Deroo BJ \& Korach KS 2005 Estrogen receptor- $\beta$ is critical to granulosa cell differentiation and the ovulatory response to gonadotropin. Endocrinology 146 3247-3262.

Drummond AE, Britt KL, Dyson M, Jones ME, Kerr JB, O’Donnell L, Simpson ER \& Findlay JK 2002 Ovarian steroid receptors and their role in ovarian function. Molecular and Cellular Endocrinology 191 27-33.
Elvin JA, Yan C, Wang P, Nishimori K \& Matzuk MM 1999 Molecular characterization of the follicle defects in the growth differentiation factor 9-deficient ovary. Molecular Endocrinology 13 1018-1034.

Endl E \& Gerdes J 2000 The Ki-67 protein: fascinating forms and unknown function. Experimental Cell Research 257 231-237.

Evans ACO \& Fortune JE 1997 Selection of the dominant follicle in cattle occurs in the absence of differences in the expression of messenger ribonucleic acid for gonadotropin receptors. Endocrinology 138 2963-2971.

Fortune JE, Sirois J \& Quirk SM 1988 The growth and differentiation of ovarian follicles during the bovine estrous cycle. Theriogenology 29 95-109.

Guo M \& Hay BA 1999 Cell proliferation and apoptosis. Current Opinion in Cell Biology 11 745-752.

Guttridge DC, Albanese C, Reuther JY, Pestell RG \& Baldwin AS 1999 NF- $\mathrm{B}$ controls cell growth and differentiation through transcriptional regulation of cyclin D1. Molecular and Cellular Biology $195785-5799$.

Hakuno N, Koji T, Yano T, Kobayashi N, Tsutsumi O, Taketani Y \& Nakane PK 1996 Fas/APO-1/CD95 system as a mediator of granulosa cell apoptosis in ovarian follicle atresia. Endocrinology 137 1938-1948.

Hengartner MO 2000 The biochemistry of apoptosis. Nature 407 770-776.

Hirshfield AN 1991 Development of follicles in the mammalian ovary. International Review of Cytology 124 43-101.

Hirshfield AN \& Midgley AR 1978 Morphometric analysis of follicular development in the rat. Biology of Reproduction 19 597-605.

Hsu CJ \& Hammond JM 1987 Gonadotropins and estradiol stimulate immunoreactive insulin-like growth factor-I production by porcine granulosa cells in vitro. Endocrinology 120 198-207.

Hu C-L, Cowan RG, Harman RM, Porter DA \& Quirk SM 2001 Apoptosis of bovine granulosa cells after serum withdrawal is mediated by Fas antigen (CD95) and Fas ligand. Biology of Reproduction 64 518-526.

Hu C-L, Cowan RG, Harman RM \& Quirk SM 2004 Cell cycle progression and activation of Akt kinase are required for IGF-1-mediated suppression of apoptosis in granulosa cells. Molecular Endocrinology 18 326-334.

Johnson AL 2003 Intracellular mechanisms regulating cell survival in ovarian follicles. Animal Reproduction Science 78 185-201.

Joyce D, Albanese C, Steer J, Fu M, Bouzahzah B \& Pestell RG 2001 $\mathrm{NF}-\mathrm{\kappa B}$ and cell-cycle regulation: the cyclin connection. Cytokine and Growth Factor Reviews 12 73-90.

Kim J-M, Boone DL, Auyeung A \& Tsang BK 1998 Granulosa cell apoptosis induced at the penultimate stage of follicular development is associated with increased levels of Fas and Fas ligand in the rat ovary. Biology of Reproduction 58 1170-1176.

King KL \& Cidlowski JA 1998 Cell cycle regulation and apoptosis. Annual Review of Physiology 60 601-617.

Kondo H, Maruo T, Peng X \& Mochizuki M 1996 Immunological evidence for the expression of the Fas antigen in the infant and adult human ovary during follicular regression and atresia. Journal of Clinical Endocrinology and Metabolism 81 2702-2710.

Lissy NA, Van Dyk LF, Becker-Hapak M, Vocero-Akbani A, Mendler JH \& Dowdy SF 1998 TCR antigen-induced cell death occurs from a late G1 phase cell cycle check point. Immunity 8 57-65.

Lussier JG, Matton P \& Dufour JJ 1987 Growth rates of follicles in the ovary of the cow. Journal of Reproduction and Fertility 81 301-307.

Meikrantz W \& Schlegel R 1995 Apoptosis and the cell cycle. Journal of Cellular Biochemistry 58 160-174.

Mihm M, Austin EJ, Good TEM, Ireland JLH, Knight PG, Roche JF \& Ireland JJ 2000 Identification of potential intrafollicular factors involved in selection of dominant follicles in heifers. Biology of Reproduction 63 811-819. 
Ormerod MG 1994 Analysis of DNA: general methods. In Flow Cytometry: A Practical Approach, pp 119-135. Ed MG Ormerod. New York, NY, USA: Oxford University Press.

Ott RL \& Longnecker M 2001 An Introduction to Statistical Methods and Data Analysis, pp 427-468. Pacific Grove, CA, USA: Duxbury.

Pedersen T 1970 Follicle kinetics in the ovary of the cyclic mouse. Acta Endocrinologica 64 304-323.

Poluha W, Poluha DK, Chang B, Crosbie NE, Schonhoff CM, Kilpatrick DL \& Ross AH 1996 The cyclin-dependent kinase inhibitor $\mathrm{p} 21^{W A F 1}$ is required for survival of differentiating neuroblastoma cells. Molecular and Cellular Biology 16 1335-1341.

Porter DA, Vickers SL, Cowan RG, Huber SC \& Quirk SM 2000 Expression and function of Fas antigen vary in bovine granulosa and theca cells during ovarian follicular development and atresia. Biology of Reproduction 62 62-66.

Porter DA, Harman RM, Cowan RG \& Quirk SM 2001 Susceptibility of ovarian granulosa cells to apoptosis differs in cells isolated before or after the preovulatory $\mathrm{LH}$ surge. Molecular and Cellular Endocrinology 176 13-20.

Quirk SM, Harman RM \& Cowan RG 2000 Regulation of Fas antigen (Fas, CD95)-mediated apoptosis of bovine granulosa cells by serum and growth factors. Biology of Reproduction 63 1278-1284.

Quirk SM, Cowan RG \& Harman RM 2004 Progesterone receptor and the cell cycle modulate apoptosis in granulosa cells. Endocrinology 145 5033-5043.

Rao MC, Midgley AR \& Richards JS 1978 Hormonal regulation of ovarian cellular proliferation. Cell 14 71-78.

Rivera GM, Chandrasekher YA, Evans ACO, Giudice LC \& Fortune JE 2001 A potential role for insulin-like growth factor binding protein-4 proteolysis in the establishment of ovarian follicular dominance in cattle. Biology of Reproduction 65 102-111.

Robker RL \& Richards JS 1998a Hormonal control of the cell cycle in ovarian cells: proliferation versus differentiation. Biology of Reproduction 59 476-482.

Robker RL \& Richards JS $1998 b$ Hormone-induced proliferation and differentiation of granulosa cells: a coordinated balance of the cell cycle regulators cyclin D2 and p27 KIP1. Molecular Endocrinology 12 924-940.

Rosenfeld CS, Yuan X, Manikkam M, Calder MD, Garverick HA \& Lubahn DB 1999 Cloning, sequencing, and localization of bovine estrogen receptor- $\beta$ within the ovarian follicle. Biology of Reproduction 60 691-697.
Rosenfeld CS, Wagner JS, Roberts RM \& Lubahn DB 2001 Intraovarian actions of oestrogen. Reproduction 122 215-226.

Scholzen T \& Gerdes J 2000 The Ki-67 protein: from the known and the unknown. Journal of Cellular Physiology 182 311-322.

Schutte B \& Ramaekers FCS 2000 Molecular switches that govern the balance between proliferation and apoptosis. Progress in Cell Cycle Research 4 207-217.

Sherr CJ \& Roberts JM 1999 CDK inhibitors: positive and negative regulators of $\mathrm{G}_{1}$-phase progression. Genes and Development 13 1501-1512.

Sicinski P, Donaher JL, Geng Y, Parker SB, Gardner H, Park MY, Robker RL, Richards JS, McGinnis LK, Biggers JD et al. 1996 Cyclin D2 is an FSH-responsive gene involved in gonadal cell proliferation and oncogenesis. Nature 384470.

Valdez KE \& Turzillo AM 2005 Regulation of nuclear factor- $\kappa B$ $(\mathrm{NF}-\mathrm{KB})$ activity and apoptosis by estradiol in bovine granulosa cells. Molecular and Cellular Endocrinology 243 66-73.

Vickers SL, Cowan RG, Harman RM, Porter DA \& Quirk SM 2000 Expression and activity of the Fas antigen in bovine ovarian follicle cells. Biology of Reproduction 62 54-61.

Wang J \& Walsh K 1996 Resistance to apoptosis conferred by Cdk inhibitors during myocyte differentiation. Science 273 359-361.

Wang Y, Chan S \& Tsang BK 2002 Involvement of inhibitory nuclear factor- $\kappa \mathrm{B}(\mathrm{NF}-\kappa \mathrm{B})$-independent NF- $\kappa \mathrm{B}$ activation in the gonadotropic regulation of $\mathrm{X}$-linked inhibitor of apoptosis expression during ovarian follicular development in vitro. Endocrinology 143 2732-2740.

Wilson GD 1994 Analysis of DNA: measurement of cell kinetics by the bromodeoxyuridine/anti-bromodeoxyuridine methods. In Flow Cytometry: A Practical Approach, pp 137-156. Ed M Ormerod. New York, NY, USA: Oxford University Press.

Xiao CW, Ash K \& Tsang BK 2001 Nuclear factor- $\kappa$ B-mediated $\mathrm{X}$-linked inhibitor of apoptosis protein expression prevents rat granulosa cells from tumor necrosis factor $\alpha$-induced apoptosis. Endocrinology 142 557-563.

Xiao CW, Asselin E \& Tsang BK 2002 Nuclear factor $\kappa$ B-mediated induction of Flice-like inhibitory protein prevents tumor necrosis factor $\alpha$-induced apoptosis in rat granulosa cells. Biology of Reproduction 67 436-441.

Received in final form 4 January 2006 Accepted 10 February 2006 